\title{
The Outlook for Financing Japan's Public Debt
}

Kiichi Tokuoka 


\title{
IMF Working Paper
}

Asia and Pacific Department

The Outlook for Financing Japan's Public Debt

Prepared by Kiichi Tokuoka

Authorized for distribution by Kenneth Kang

January 2010

\begin{abstract}
This Working Paper should not be reported as representing the views of the IMF. The views expressed in this Working Paper are those of the author(s) and do not necessarily represent those of the IMF or IMF policy. Working Papers describe research in progress by the author(s) and are published to elicit comments and to further debate.

Despite the rapid rise in public debt and large fiscal deficits, Japanese Government Bond (JGB) yields have remained fairly stable. Possible factors include: Japan's sizeable pool of household savings, presence of large and stable institutional investors, and strong home bias. These factors are likely to persist for some time, but going forward, the market's capacity to absorb debt is likely to diminish, as population aging reduces savings inflows and financial reforms enhance risk appetite. This could in turn strengthen the link between JGB yields and the stock of public debt. In light of these structural changes in the market, fiscal consolidation will be key for maintaining market stability.
\end{abstract}

JEL Classification Numbers: E43, E62

Keywords: Public debt, fiscal deficits, Japanese government bonds, yields

Author's E-Mail Address:ktokuoka@imf.org 


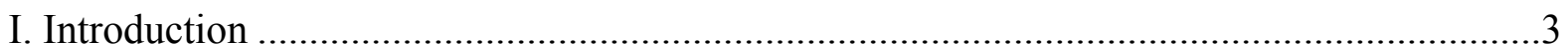

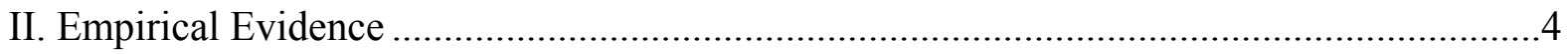

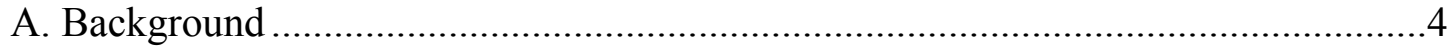

B. Cross-Country Analysis of Factors Driving Yields …........................................

Outline of Regressions ...........................................................................

Main Findings .................................................................................. 6

Alternative High-frequency Analysis .................................................

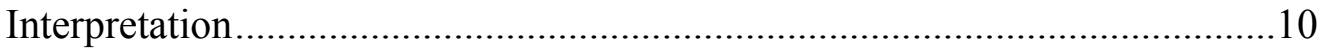

C. Explanation of the Low Sensitivity of JGB Yields ...........................................11

III. Outlook for Absorption Capacity of the JGB Market......................................................15

Household Sector ............................................................................. 15

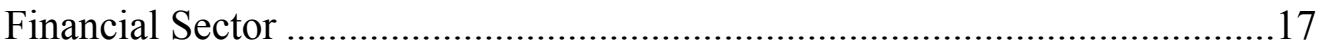

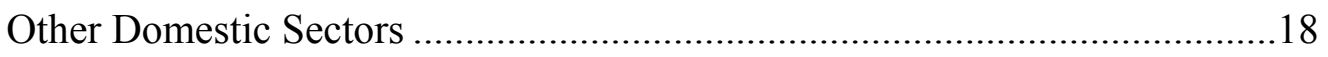

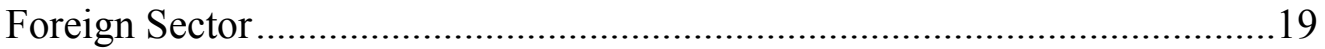

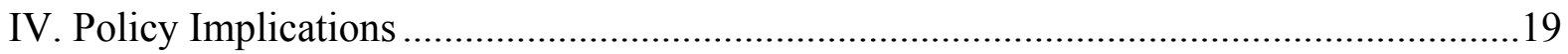

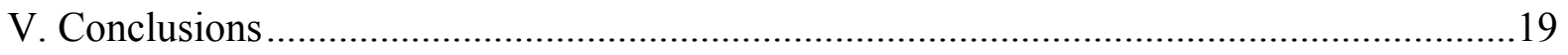

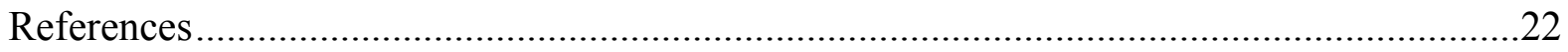

Tables

II.1. Summary of Country by Country Regression Results ...........................................

II.2. Country by Country Regression Results ....................................................................8

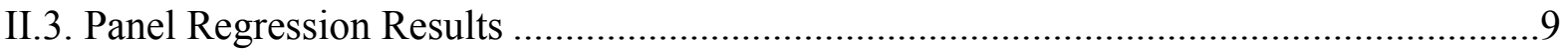

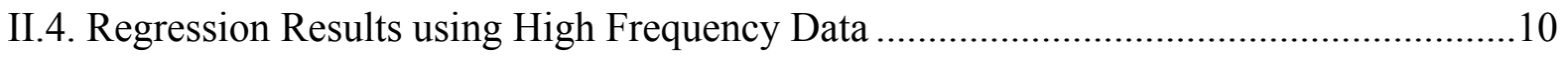

II.5. Share of JGB Holdings............................................................................................. 12

II.6. Japan-Quarterly Regression Results ............................................................... 14

Figures

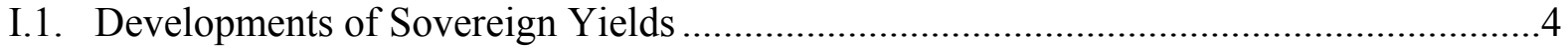

II.1. 10-year Bond Yield and Primary Balance................................................................. 13

III.1. Flow of Funds of the Household Sector ....................................................................16

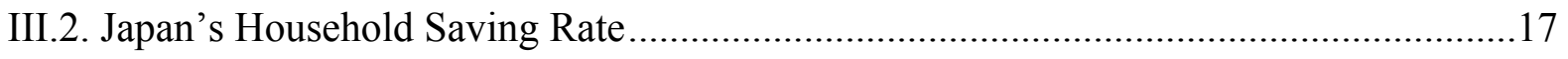

Appendixes

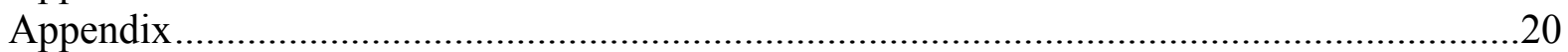




\section{INTRODUCTION}

1. Since the early 1990s, JGB yields and fiscal variables, such as public debt and the deficits do not appear to be linked. During the 1990s the 10-year Japanese Government Bond (JGB) yields declined steadily from 7 percent to below 2 percent, while net public rose from 20 percent of GDP to 60 percent of GDP. Since 2000, net public debt has further climbed to 90 percent of GDP, while long term yields have remained fairly stable at below 2 percent.

2. More recently, fiscal deficits have again widened sharply, reflecting both discretionary measures and automatic stabilizers in response to the global slowdown. JGB yields picked up in early 2009 following announcements of a series of stimulus packages, but they still remain low by historical standard. With the general government deficit projected to stay around 10 percent of GDP in 2010, public debt will exceed 110 percent of GDP in net terms (225 percent of GDP in gross terms) - the highest among advanced economies.

3. Can these benign conditions holding down JGB yields be expected to continue in the face of continuing increases in public debt? To answer this question, the paper examines factors behind the low and steady JGB yields, including Japan's large and growing pool of household savings, stable institutional investors, and strong home bias, and assesses how these structural factors may evolve over time to affect Japan's public debt finances. The main conclusion is that in the near term, these factors are likely to persist helping to keep down JGB yields, but that over time, the market's capacity to absorb public debt will likely diminish as population aging reduces savings inflows and financial reforms enhance risk appetite. Sound public debt management can help preserve market stability, but over a longer-horizon, fiscal consolidation will become critical for ensuring the smooth financing of government operations.

4. This paper is structured as follows. The next section reports empirical evidence highlighting the insensitivity of JGB yields, and then considers factors which may explain this observation. Section III discusses the outlook for the market's capacity to absorb public debt. Section IV briefly discusses policy implications, followed by conclusions. 
Figure I.1: Developments of Sovereign Yields

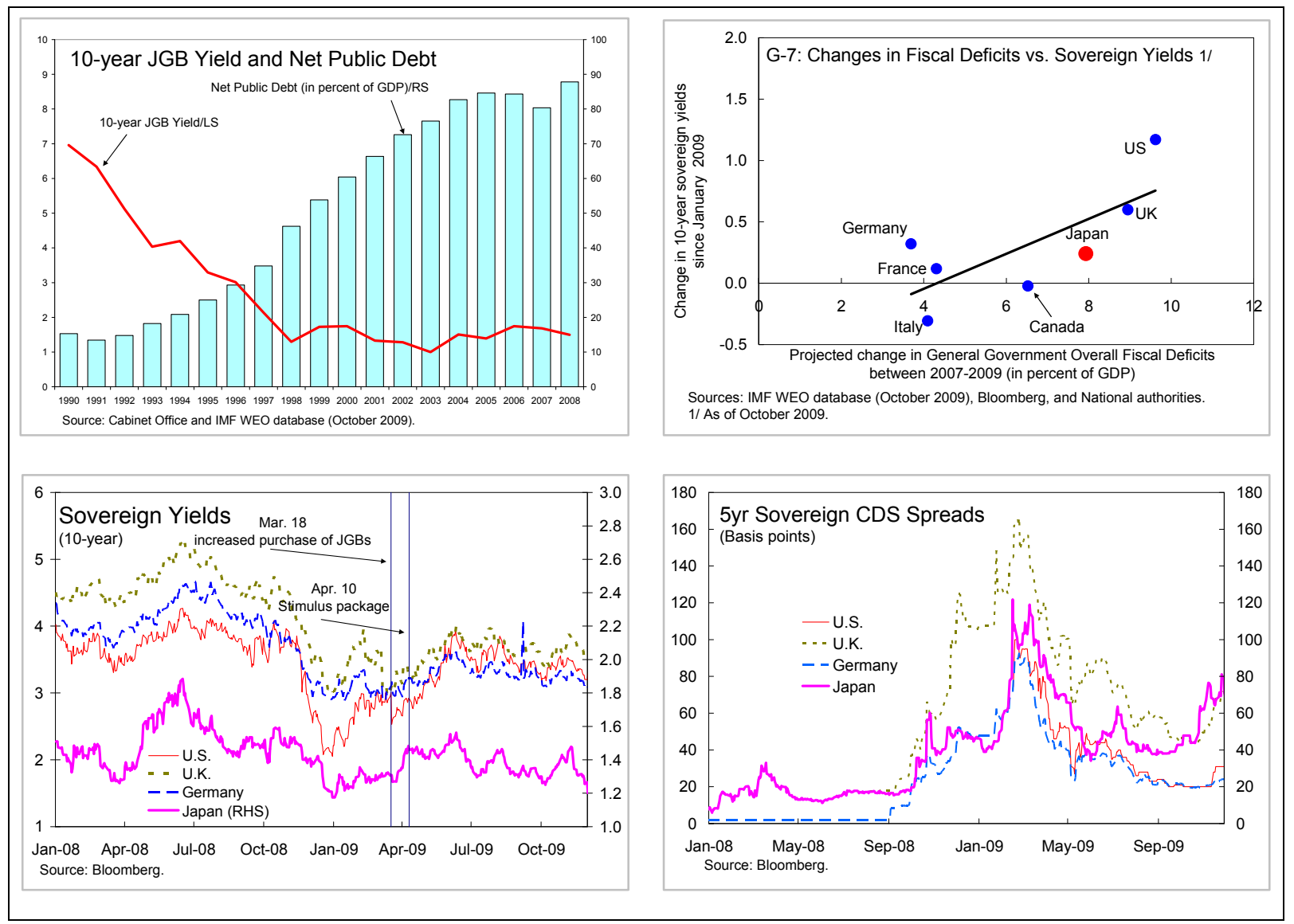

\section{EMPIRICAL EVIDENCE}

\section{A. Background}

5. Standard theory suggests that either fiscal deficits or the stock of debt should have a positive relation with government bond yields. A textbook IS-LM framework predicts that deficits to finance expansionary fiscal policy would raise interest rates. On the other hand, standard neoclassical theory often argues that ultimately it is the stock of debt that mattersin equilibrium, the real interest rate should equal the marginal productivity of capital, and thus the size of crowding-out of private capital by public debt should matter. Under some extreme assumptions, neoclassical models predict Ricardian equivalence (neither deficits nor debt affects yields), but from a theoretical perspective, Ricardian equivalence may be hard to rationalize (e.g., Bernheim, 1989). Once plausible elements such as a finite horizon (Blanchard, 1985) are incorporated, the models produce a positive relation between debt and yields. ${ }^{1}$

\footnotetext{
${ }^{1}$ On the empirical front, whether Ricardian equivalence is a good approximation is still an open question. While Seater (1993) finds overall support for Ricardian equivalence, Gale and Orszag (2003) argue the opposite.
} 
6. The empirical literature has typically examined the impact of deficits or debt on longterm government bond yields. In studies which test fiscal deficits across countries, the estimated impact of an increase in the fiscal deficit by 1 percent of GDP on long-term government bond yields ranges from 10 to 60 basis points. ${ }^{2}$ The other strand, which examines the impact of debt on yields using either a general or partial equilibrium model, ${ }^{3}$ finds that a 1 percent of GDP increase in debt would raise yields by at most 10 basis points.

Interpretations of the smaller coefficients on the debt differ depending on the underlying theoretical framework. For example, under a neoclassical framework, the interpretation could be that the high persistence of deficits may provide better information about the future path of debt which could affect current yields.

7. There are some studies which include both the deficit and debt in the estimated equation (e.g., Faini, 2006; Caparole and Williams, 2002). A rationale for including the deficit in addition the stock of debt is that forward looking households care about future debt dynamics whose information can be found in the deficit. While these studies find a significant impact of deficits on yields, the inclusion of both deficits and debt makes interpretation of the estimates harder. For example, Faini (2006), who includes both variables in the estimated equation, simply concludes that expansionary fiscal policy has a positive effect on government bond yields.

\section{B. Cross-Country Analysis of Factors Driving Yields}

8. This paper starts with country-by-country regressions either with the fiscal deficit or public debt as the main explanatory variable to see whether JGB yields are historically less sensitive to fiscal variables than other G7 sovereign bonds. The main purpose of these regressions is not to pin down the impact of the fiscal deficits or the stock of debt on longterm government bond yields, but to obtain benchmark results to help interpret key differences between Japan's government bond market and those in other advanced economies. The outline of the regressions and main findings are as follows:

\section{Outline of Regressions}

9. The dependent variable is the nominal (or real) 10-year government bond yield. The main explanatory variable is either the general government primary deficit (in percent of

\footnotetext{
${ }^{2}$ Recent work which estimates the impact of fiscal deficits includes Baldacci, Gupta and Mati (2008), Hauner and Kumar (2006), and Ardagna, Caselli, and Lane (2004). While Baldacci, Gupta and Mati (2008) use data on emerging market economies, the latter two focus on advanced economies (Hauner and Kumar (2006) on G7, and Ardagna, Caselli, and Lane (2004) on OECD countries). See Brook (2003) for a comprehensive list of earlier estimates (both the impacts of deficits and public debt).

${ }^{3}$ Recent empirical work includes Kinoshita (2006), Engen and Hubbard (2004), and Laubach (2003). Kinoshita (2006) relies on data on OECD countries, while the latter two use the U.S. debt forecasted by the government.
} 
GDP) or general government debt (in percent of GDP) at the end of the previous year (the debt is measured in both net and gross terms). The primary deficit is used instead of the overall deficit as an explanatory variable, since the overall deficit includes interest payment, creating an endogeneity problem. Standard controls, such as short-term interest rate (3-month deposit rate), inflation, and real GDP growth, are included in the regressions. ${ }^{4}$ The data are measured annually and cover 1971-2008 for Japan, the U.S., and Canada and a somewhat shorter time period for other countries due to data availability. ${ }^{5}$ Stationarity assumptions on the data are discussed in the Appendix.
(1) nominal 10-year bond yield
(2) real 10-year bond yield
$=\beta 0+\beta 1$ primary deficit + control variables
(3) nominal 10-year bond yield
$=\beta 0+\beta 1$ primary deficit + control variables
$=\beta 0+\beta 1$ net debt + control variables
(4) nominal 10-year bond yield
$=\beta 0+\beta 1$ gross debt + control variables

Estimated Equations: ${ }^{6}$

\section{Main Findings}

10. The results point to a weaker impact of the primary deficit on JGB yields.

- Japan. When the fiscal variable (main explanatory variable) is the primary deficit, the coefficient is relatively small (at most 0.1 ) and statistically insignificant. When net or gross debt is included as the main explanatory variable, the coefficient turns negative. ${ }^{7}$ The results are generally consistent across alternative specifications, and do not change much, even if the nominal (or real) U.S. 10-year bond yield-as a proxy for international liquidity conditions - is included as an explanatory variable. ${ }^{8}$ Similarly, excluding central government debt held by the central bank from net or

\footnotetext{
${ }^{4}$ As an alternative specification, the current account balance (in percent of GDP) is included, but does not significantly affect the results.

${ }^{5}$ The data is from the IMF WEO database (October 2009).

${ }^{6}$ The real 10 -year bond yield is not regressed on debt, since the yield is assumed to be stationary while debt is unlikely to be so (see the Appendix).

${ }^{7}$ This paper is not the first to report a negative coefficient on public debt. Some earlier articles have also reported negative coefficients (e.g., Ardagna, Caselli, and Lane, 2004; Caporale and Williams, 2002). One possible interpretation of the negative sign is that when the level of sovereign debt is low and investors believe that the debt is of high quality, they may switch from low quality to sovereign debt as more sovereign debt is issued, reducing the yield (Caporale and Williams, 2002).

${ }^{8}$ When the nominal U.S. 10 -year bond yield is an explanatory variable, cointegration with other variables is assumed.
} 
gross debt does not affect the results. ${ }^{9}$ Finally, restricting the sample to the predeflation period (before 1995) gives a relatively large and significant coefficient on the primary deficit (around 0.2), but generally speaking this is still smaller than other countries' coefficients (see below).

- $\quad$ Other countries. For other countries, coefficients on the primary deficit are generally positive and statistically significant (highly significant for the U.S., U.K., and Canada). The coefficients lie between $0.15-0.40$ (except for Italy), which is in the range of recent estimates obtained using data on advanced economies (e.g., Hauner and Kumar, 2006; Ardagna, Caselli, and Lane, 2004; Laubach, 2003). These estimates can be interpreted as stating that an increase in the primary deficit by one percent of GDP leads to an increase in the 10-year government bond yield by 15 40 basis points. On the other hand, most of the coefficients on net or gross debt are again negative.

Table II.1. Summary of Country by Country Regression Results

\begin{tabular}{|c|c|c|}
\hline & Primary Deficit & Net/Gross Debt \\
\hline Japan & $\begin{array}{l}\text { The coefficients are at most } 0.10 \\
\text { and statistically insignificant. }\end{array}$ & The coefficients are negative. \\
\hline U.S., U.K., and Canada & $\begin{array}{l}\text { The coefficients are in the range } \\
\text { of } 0.20-0.40 \text { and statistically } \\
\text { significant at the } 1 \text { percent level. }\end{array}$ & $\begin{array}{l}\text { The coefficients are negative } \\
\text { or close to zero. }\end{array}$ \\
\hline France and Germany & $\begin{array}{l}\text { The coefficients are in the range } \\
\text { of } 0.15-0.30 \text { and statistically } \\
\text { significant at least at the } 10 \\
\text { percent level. }\end{array}$ & The coefficients are negative. \\
\hline Italy & The coefficients are negative. & $\begin{array}{l}\text { The coefficients are close to } \\
\text { zero. }\end{array}$ \\
\hline
\end{tabular}

\footnotetext{
${ }^{9}$ Engen and Hubbard (2004) argue that the effect of government debt held by the central bank, which does not crowd out domestic private capital, should be appropriately controlled for.
} 
Table II.2. Country by Country Regression Results

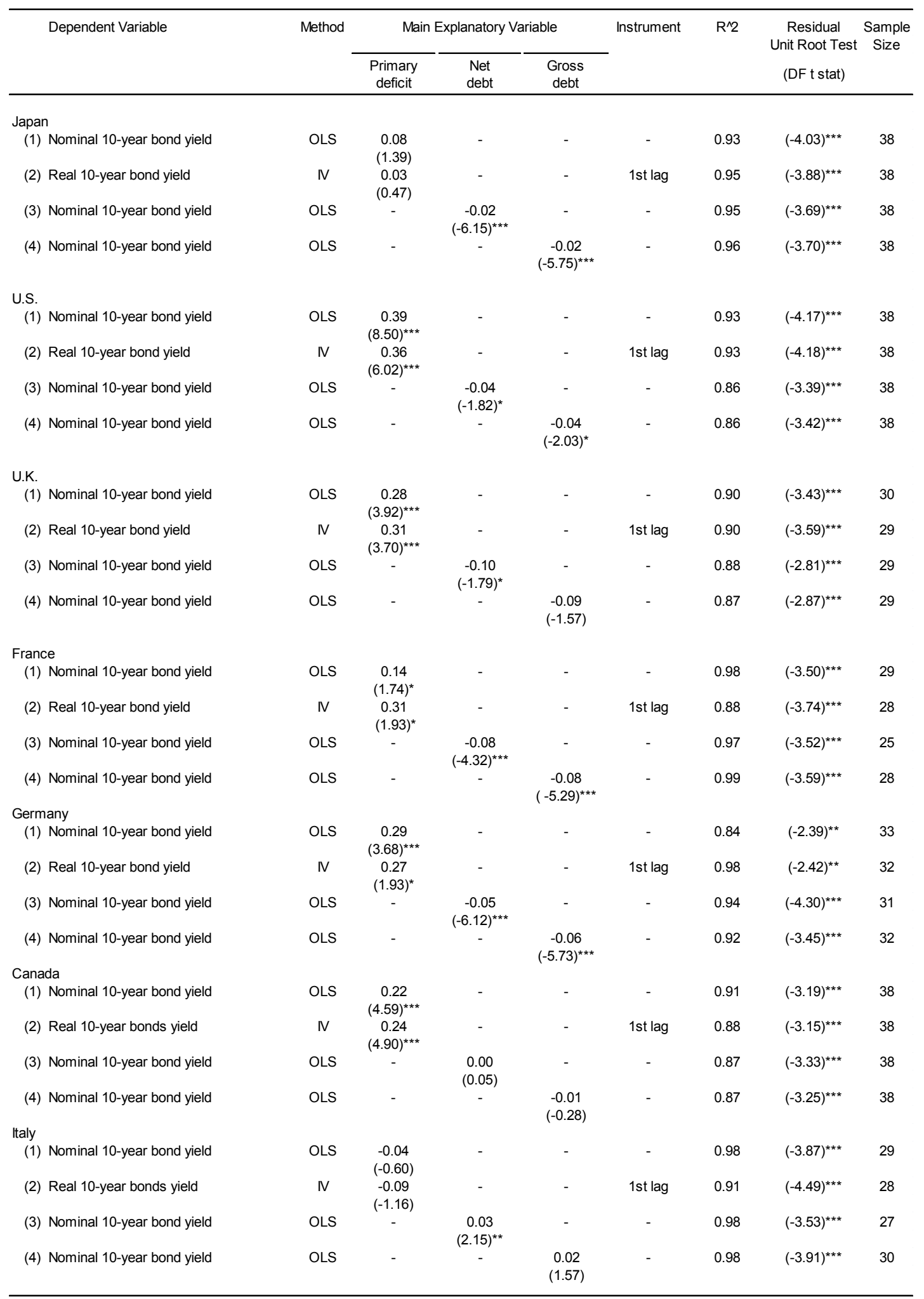

Source: IMF WEO database (October 2009)

$1 /$ Robust t statistics are reported in parentheses.

$2 /{ }^{* \star *},{ }^{* *}$, and * indicate the statistical significance at the 1 percent, 5 percent, and 10 percent, respectively. 
11. Panel regressions which pool the G7 countries highlight the weaker impact of the primary deficit on JGB yields. ${ }^{10}$ In these regressions, the primary deficit multiplied by a Japan dummy variable is included as an additional explanatory variable (this variable is instrumented with its first lag). The coefficient measures the difference in the impact of the primary deficit between Japan and other countries. As shown in Table II.3, this coefficient is between -0.1 and -0.25 (and statistically significant), implying that an increase in the primary deficit by 1 percent of GDP has a smaller impact on JGB yields by 10-25 basis points compared to other countries. This also means that the overall impact of primary deficits on JGB yields is close to zero, given that the coefficient on the primary balance for all countries is about $0.15-0.20$.

Table II.3. Panel Regression Results

\begin{tabular}{|c|c|c|c|c|c|c|c|}
\hline & \multirow[t]{2}{*}{ Dependent Variable } & \multirow[t]{2}{*}{ Method } & \multicolumn{2}{|c|}{ Main Explanatory Variables } & \multirow[t]{2}{*}{ Instruments } & \multirow[t]{2}{*}{$\mathrm{R}^{\wedge} 2$} & \multirow{2}{*}{$\begin{array}{l}\text { Sample } \\
\text { Size }\end{array}$} \\
\hline & & & $\begin{array}{l}\text { Primary } \\
\text { deficit }\end{array}$ & $\begin{array}{l}\text { Primary deficit } \\
\text { *Japan dummy }\end{array}$ & & & \\
\hline (1) & Real 10 -year bond yield $1 /$ & OLS & $\begin{array}{c}0.15 \\
(3.95)^{\star \star \star}\end{array}$ & $\begin{array}{c}-0.20 \\
(-3.68)^{\star \star \star}\end{array}$ & - & 0.91 & 235 \\
\hline (2) & Real 10 -year bond yield $1 /$ & $\begin{array}{l}\text { Instrumental } \\
\text { Variable }\end{array}$ & $\begin{array}{c}0.16 \\
(4.29)^{\star \star *}\end{array}$ & $\begin{array}{c}-0.23 \\
(-3.83)^{\star * *}\end{array}$ & $\begin{array}{l}\text { 1st Lag of Main } \\
\text { Explanatory Variables }\end{array}$ & 0.90 & 231 \\
\hline (3) & Real 10 -year bond yield & $\begin{array}{l}\text { Fixed Effects } \\
\text { Estimator }\end{array}$ & $\begin{array}{c}0.18 \\
(5.71)^{\star \star \star}\end{array}$ & $\begin{array}{c}-0.12 \\
(-1.76)^{*}\end{array}$ & - & 0.91 & 235 \\
\hline
\end{tabular}

\section{Alternative High-frequency Analysis}

12. The lower sensitivity of JGB yields to fiscal deficits can also be confirmed with high frequency data for Japan and the U.S. Every month, Consensus Economics Inc. releases the means of various macro and fiscal forecasts by private institutions, which can be used to estimate the impact of changes in the forecasted fiscal deficit on yields. Specifically, the 12month-ahead forecast for the nominal 10-year government bond yield (in percent) is the dependent variable, and the forecast for the overall fiscal deficit (in percent of GDP) in next

\footnotetext{
${ }^{10}$ Regressions which involve only stationary variables are conducted (nominal 10-year bond yield, which is assumed to be nonstationary, is not used as a dependent variable). The set of control variables is the same as that in earlier country-by-country regressions: real short-term interest rate (3-month deposit rate), inflation, and real GDP growth. Including the current account balance does not change the results.
} 
U.S. fiscal year is the main explanatory variable. ${ }^{11}{ }^{12}$ Control variables are the 12 -monthahead forecast for the short-term interest rate (3-month deposit rate) and forecasts for inflation and real GDP growth in the next calendar year. Table II.4 reports that the coefficient on the overall fiscal deficit is about zero for Japan-well below the U.S. coefficient $(0.09) .{ }^{13}$

Estimated Equation:

nominal 10-year bond yield (12-month-ahead) $\quad=\beta 0+\beta 1$ forecasted overall fiscal deficit + controls

Table II.4. Regression Results using High Frequency Data

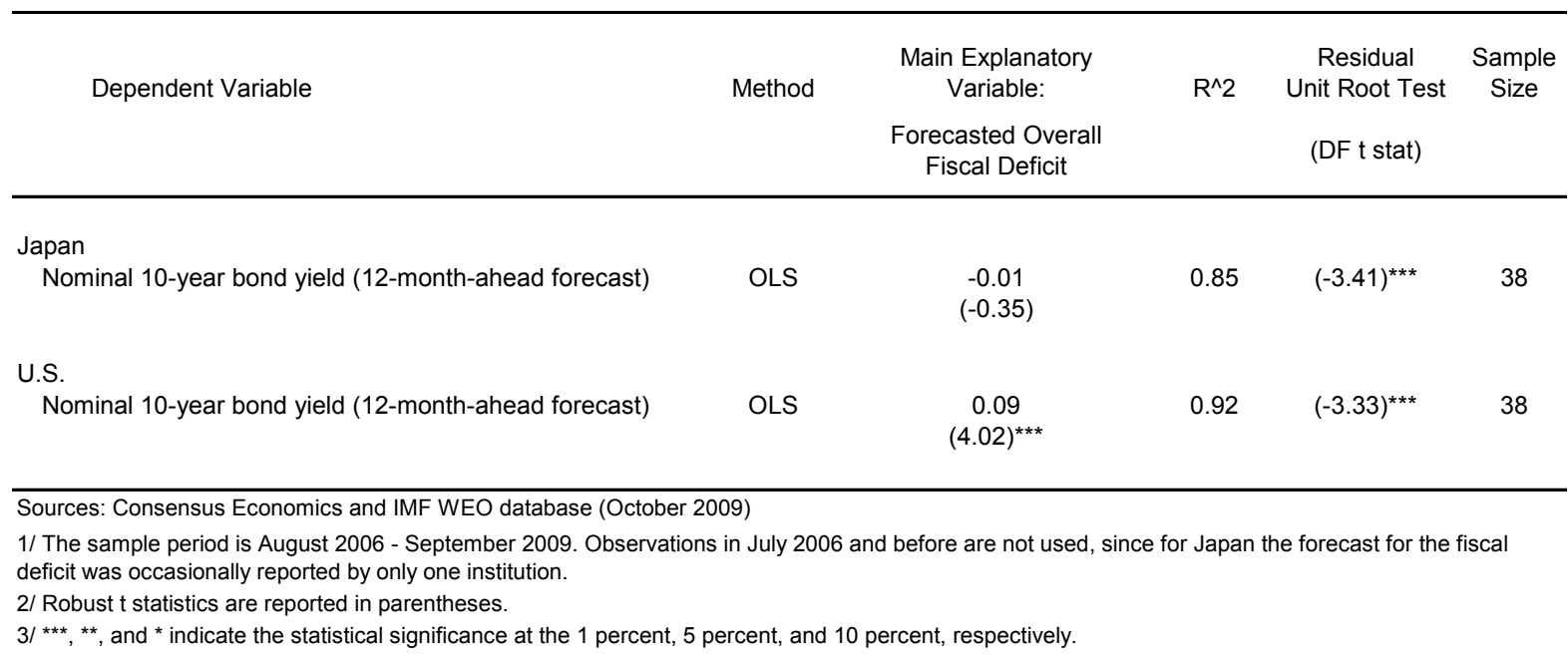

\section{Interpretation}

13. All these results suggest that Japanese government bond yields are less sensitive to fiscal deficits than in other countries, but they should be interpreted with caution. In particular, the results may be subject to the omitted variable bias even after using the instrumental variable method. For example, today's yield may be affected by various current business cycle variables, which are not fully accounted for by growth or short-term monetary

${ }^{11}$ Ideally, the forecast for the nominal 10-year government bond yield in next U.S. fiscal year should be used as the main dependent variable in line with the main explanatory variable, but Consensus Economics Inc. does not provide that.

12 "Next U.S. fiscal year" is defined as a fiscal year ending in September next calendar year. For example, in October 2009, "next U.S. fiscal year" corresponds to October 2009-September 2010. To allow a comparison of estimation results between Japan and the U.S., Japan's fiscal deficits are converted into the U.S. fiscal year basis, by taking averages of fiscal deficits reported on Japan's fiscal year basis.

${ }^{13}$ Cointegration among the variables (except for the real GDP growth forecast) is assumed. P-values of the Dickey-Fuller t-statistics are high across the dependent and explanatory variables (typically over 0.7 ) except for the real GDP growth forecast. 
conditions (which are included in the regressions as controls) but may be correlated with deficits. In principle, it is possible to avoid this problem, for example, by regressing future (expected) yields on official forecasts for deficits far enough in the future (e.g., 5-10 years). ${ }^{14}$ However, such an analysis is currently not feasible for Japan, as the Japanese Cabinet Office started to publish its 5-year forecasts for the deficit and the stock of debt only a few years ago. The effect of the immediate business cycle might have been mitigated somewhat by using the data from Consensus Economics, but given its short forecast horizon (one year), the results in Table II.4 are still likely to be significantly affected by the current business cycle.

\section{Explanation of the Low Sensitivity of JGB Yields}

14. Empirical results in the previous subsection suggest that Japan-specific factors, which are not included in the regression analysis, may be contributing to the observed lower sensitivity of JGB yields compared to other sovereign bonds (IMF, 2009). These include:

- $\quad$ Large pool of household assets. Japan had enjoyed relatively high household saving rates (over 10 percent) until around 1999 when they began to decline sharply. High savings were typically attributed to various factors, ${ }^{15}$ such as the seniority wage system, the existence of sizeable bonuses, rapid growth, and sluggishness of consumption (habits). ${ }^{16}$ Although a firm consensus is lacking on this issue, the ample saving flows have contributed to large accumulation of household financial assets, helping finance the build-up of public debt.

- $\quad$ Strong home bias. JGBs have been financed largely by domestic investors (94 percent of holdings as of end-2008), who may exhibit more stable behavior than foreign investors. The strong home bias is driven by the household sector whose appetite for risky assets has remained weak. ${ }^{17}$ The share of currency and deposits in households' financial assets is as high as 55 percent (at end FY2008)—well above 16 percent in the U.S. - and a large part of these funds is invested in JGBs mainly through the banking sector.

\footnotetext{
${ }^{14}$ Eugen and Hubbard (2004) and Laubach (2003) find empirical evidence that in the U.S. future (expected) yields are responsive to 5 or 10 year government forecasts for fiscal variables (deficits and/or debt).

${ }^{15}$ See Horioka (1990) and Ishikawa (1988) for a comprehensive list of possible factors.

${ }^{16}$ Habits, if exists, can raise savings rates following a period of high economic growth (as experienced by Japan during the 1960-1970s), since they delay consumption adjustments (Carroll, Overland, and Weil, 2000).

${ }^{17}$ Nakagawa and Shimizu (2000) report that Japanese households typically place more emphasis on the safety of their financial investments. However, others argue that historically high real estate prices in Japan may have encouraged households to accumulate safe financial assets to achieve a right balance between risky assets including housing and safe assets (e.g., Iwaisako, 2003; Iwaisako, Mitchell, and Piggott, 2004).
} 
- $\quad$ Existence of large and stable institutional holders. The Japan Post Bank (previously the postal savings) and the Government Pension Investment Fund have invested about $¥ 250$ trillion in JGBs (around 35 percent of the total JGBs). ${ }^{18}$ The government has relied on these institutions to help finance their lending operations. On top of these institutions, the Bank of Japan (BoJ) also held nearly $¥ 60$ trillion of JGBs as of end2008.

Table II.5. Share of JGB Holdings (in percent) 1/

\begin{tabular}{|c|c|c|c|c|c|}
\hline & Dec-00 & Dec-05 & Dec-06 & Dec-07 & Dec-08 \\
\hline $\begin{array}{l}\text { Government 2/ } \\
\text { Of which: }\end{array}$ & 23.1 & 15.9 & 14.3 & 13.8 & 13.2 \\
\hline Public Pension & 2.8 & 9.2 & 9.8 & 11.1 & 11.8 \\
\hline Bank of Japan (BoJ) & 11.9 & 14.0 & 11.2 & 9.5 & 8.3 \\
\hline $\begin{array}{l}\text { Financial institutions } \\
\text { Of which: }\end{array}$ & 55.1 & 59.9 & 62.2 & 62.0 & 64.2 \\
\hline Postal Savings & 7.0 & 18.5 & 20.3 & . & . \\
\hline Banks 3/ & 22.3 & 17.0 & 16.3 & 35.0 & 36.2 \\
\hline Overseas & 5.9 & 4.7 & 5.5 & 7.0 & 6.4 \\
\hline Households & 2.2 & 4.0 & 4.8 & 5.3 & 5.3 \\
\hline Others 4/ & 1.8 & 1.6 & 2.0 & 2.3 & 2.5 \\
\hline Total (in trillions of yen) & 391.2 & 672.1 & 674.6 & 682.4 & 697.3 \\
\hline $\begin{array}{l}\text { Total excluding FILP bonds } \\
\text { (in trillions of yen) }\end{array}$ & 391.2 & 535.8 & 534.8 & 538.2 & 558.0 \\
\hline
\end{tabular}

Source: BoJ's Flow of Funds statistics.

$1 /$ JGBs are the general account bonds and the Fiscal Investment Loan Program (FILP) bonds, and do not include financing bills.

2/ Includes the FILP.

3/ Includes Japan Post Bank for Dec-07 and Dec-08.

4/ Nonfinancial corporations and private nonprofit institutions serving households.

- $\quad$ Recent large saving flows from the corporate sector. Over the past ten years, the corporate sector has been playing a supporting role in channeling funds to the JGB market. Following its recovery from the crisis in the 1990s, the corporate sector has been recording financial surpluses along with the household sector. ${ }^{19}$ During the early and mid-2000s, the large financial surpluses in the corporate sector were a common phenomenon across advanced economies. IMF

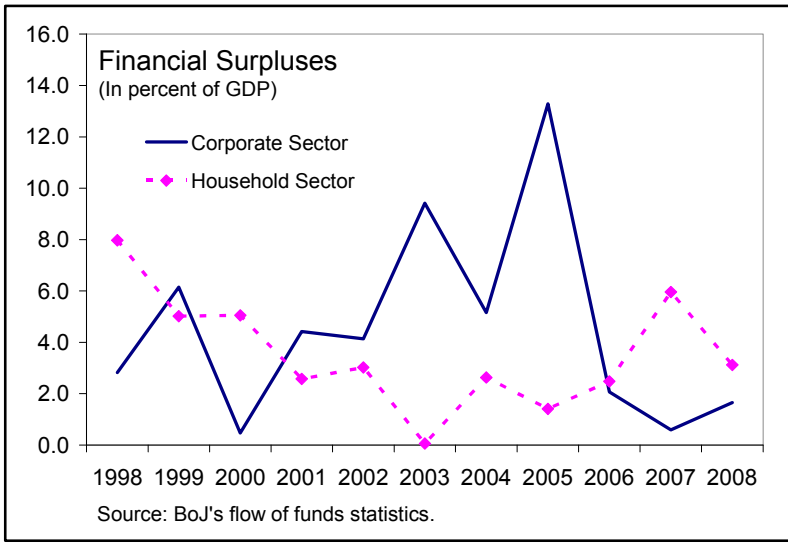

\footnotetext{
${ }^{18}$ Japan Post Bank has invested $¥ 156$ trillion in JGBs as of September 2008, while the Government Pension Investment Fund held $¥ 82$ trillion of JGBs as of end-2008.

${ }^{19}$ Financial surpluses are defined as a change in financial assets minus a change in financial debt.
} 
(2006) finds that this was driven by both higher profits and declining prices of capital goods. In Japan, the surpluses were accompanied by restructuring in the corporate sector (repayment of debt) throughout the early 2000 s.

15. In addition, despite the large fiscal deficits (Figure II.1), public gross debt has not increased over the past 10 years, if government liabilities under the Fiscal Investment and Loan Program (FILP liabilities) are included. ${ }^{20}$ As a result of the FILP reform, which aimed to rationalize FILP lending to public agencies, FILP lending has shrunk, forcing these agencies to curtail their projects and rely more on private financing. This has reduced FILP

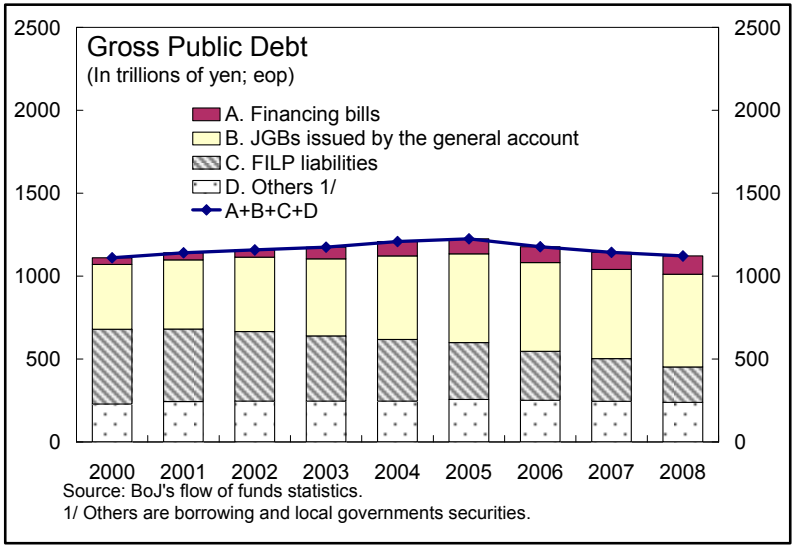
liabilities substantially by around half to about $¥ 200$ trillion (40 percent of GDP) since 2000 , and has effectively created space for financing other government debt. ${ }^{21}$

Figure II.1. 10-year Bond Yield and Primary Balance

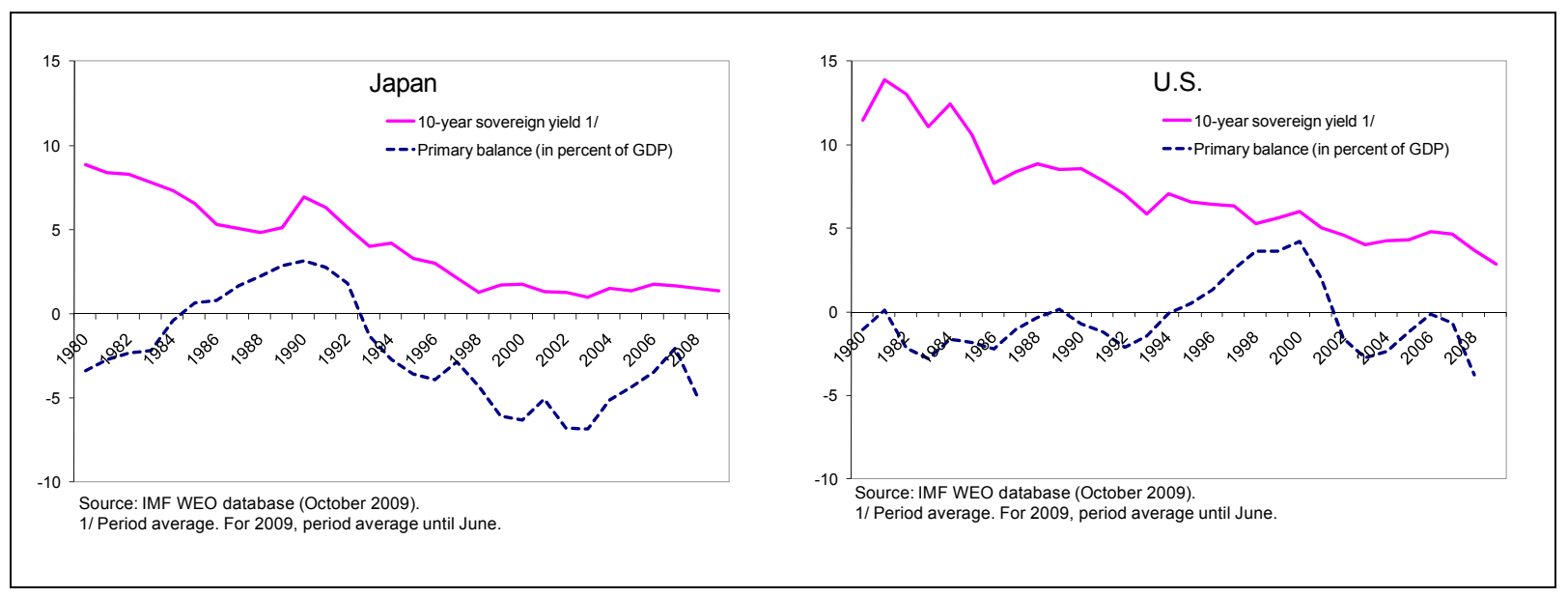

16. With BoJ's flow of funds statistics, we can empirically test for many of these Japanspecific factors. The advantage with the flow of funds statistics is that they report (quarterly) FILP liabilities and each sector's financial assets including the foreign sector. Using the data between 1998 and 2009, we re-estimates the impact of debt on JGB yields with gross debt

\footnotetext{
${ }^{20}$ Under the FILP, the government provides funds to various government affiliated corporations for implementing public projects, such as for infrastructure. The general government debt on the SNA basis excludes FILP liabilities because FILP operations are not financed by taxes and the FILP is regarded as a public agency.

${ }^{21}$ In the market, FILP bonds (which the FILP issues to finance its lending) are identical to JGBs.
} 
including FILP liabilities (in percent of GDP) as the main explanatory variable. ${ }^{22}$ The estimated equation includes additional control variables: central government debt held by the BoJ (in percent of GDP); the sum of net financial wealth held by the household and corporate sectors (in percent of GDP); and the share of foreign holdings of JGBs. ${ }^{23}$ The dependent variable is the nominal 10-year government bond yield.

nominal 10-year bond yield

\section{Estimated Equation:}

$=\beta 0+\beta 1$ gross debt including FILP liabilities + controls

17. The estimation results are very different from those reported earlier without the Japan-specific factors. The coefficient on gross debt, which was negative in Table II.2, turns to the expected positive, and it is highly significant (third row in Table II.6). The size of the coefficients is around 0.02 , implying that an increase in public debt by 1 percent of GDP would result in a rise in JGB yields by 2 basis points. While the coefficient on the central government debt held by the BoJ is positive and insignificant, the coefficients on the net household and corporate financial wealth and the share of foreign JGB holdings have expected signs and are significant. These results suggest that Japan specific factors have helped keep yields low despite the increase in JGBs and that omitting them would lead to biased results.

Table II.6. Japan-Quarterly Regression Results

\begin{tabular}{|c|c|c|c|c|c|c|c|c|c|c|c|}
\hline & \multirow[t]{2}{*}{ Dependent Variable } & \multirow[t]{2}{*}{ Method } & \multicolumn{3}{|c|}{ Main Explanatory Variable } & \multirow[b]{2}{*}{$\begin{array}{c}\text { Central } \\
\text { government } \\
\text { debt held by } \\
\text { BoJ }\end{array}$} & \multirow[b]{2}{*}{$\begin{array}{l}\text { Net financial } \\
\text { wealth held by } \\
\text { household and } \\
\text { corporate } \\
\text { sectors }\end{array}$} & \multirow[b]{2}{*}{$\begin{array}{l}\text { Share of } \\
\text { foreign holdings } \\
\text { of JGBs }\end{array}$} & \multirow[t]{2}{*}{$\mathrm{R}^{\wedge} 2$} & \multirow{2}{*}{$\begin{array}{c}\text { Residual } \\
\text { Unit Root Test }\end{array}$} & \multirow{2}{*}{$\begin{array}{c}\text { Sample } \\
\text { Size }\end{array}$} \\
\hline & & & $\begin{array}{l}\text { Gross debt } \\
\text { excluding FILP }\end{array}$ & $\begin{array}{c}\text { Gross debt } \\
\text { including FILP }\end{array}$ & $\begin{array}{c}\text { Gross debt } \\
\text { including FILP } \\
\text { minus } \\
\text { debt held by BoJ }\end{array}$ & & & & & & \\
\hline (1) & Nominal 10-year bond yield & OLS & $\begin{array}{c}0.00 \\
(0.08)\end{array}$ & & & & & & 0.16 & $(-3.28)^{\star \star \star}$ & 45 \\
\hline (2) & Nominal 10-year bond yield & OLS & & $\begin{array}{c}0.00 \\
(0.05)\end{array}$ & & & & & 0.16 & $(-3.28)^{\star \star \star}$ & 45 \\
\hline (3) & Nominal 10-year bond yield & OLS & & $\begin{array}{c}0.02 \\
(3.52)^{\star \star \star}\end{array}$ & & $\begin{array}{c}0.01 \\
(0.36)\end{array}$ & $\begin{array}{c}-0.02 \\
(-3.37)^{\star \star \star}\end{array}$ & $\begin{array}{c}0.11 \\
(2.06)^{\star \star}\end{array}$ & 0.38 & $(-3.93)^{\star \star \star}$ & 45 \\
\hline (4) & Nominal 10-year bond yield & OLS & & & $\begin{array}{c}0.02 \\
(2.77)^{\star \star \star}\end{array}$ & & $\begin{array}{c}-0.01 \\
(-3.34)^{\star \star \star}\end{array}$ & $\begin{array}{c}0.08 \\
(1.84)^{\star}\end{array}$ & 0.33 & $(-3.76)^{\star \star \star}$ & 45 \\
\hline
\end{tabular}

Source: BoJ's flow of funds statistics.

1/The sample period is between Q1 1998 and Q1 2009

2/ Robust t statistics are reported in parentheses.

$3 / * * * * *$ and * indicate the statistical significance at the 1 percent, 5 percent, and 10 percent, respectively.

\footnotetext{
${ }^{22}$ Even though the statistics under the new standard start only in late 1997, their quarterly frequency offers as many as 45 observations.

${ }^{23}$ To capture the effect of financial surpluses in the corporate sector (discussed earlier), net financial wealth rather than gross financial wealth is used. Despite the large financial surpluses in the corporate sector in the early 2000 s, its gross financial wealth declined during this period. As before, short-term interest rate, inflation rate, and real GDP growth are included as control variables. All the dependent and explanatory variables are assumed to be stationary ( $p$-values of the Dickey-Fuller t-statistics are below 0.2 except for the share of foreign JGB holdings (the p-statistic is about 0.6)).
} 


\section{OUTLOOK FOR ABSORPTION CAPACITY OF THE JGB MARKET}

18. Looking ahead, structural shifts in household balance sheets and key market players could weaken the absorptive capacity of the JGB market, making yields more sensitive to the debt level as standard theory predicts. ${ }^{24}$ These include:

\section{Household Sector}

- A large portion of JGBs is essentially financed by the household sector. While direct holdings of JGBs are only 5 percent of the total outstanding amount, if indirect channels are taken into account, households finance at least 50 percent of the total JGBs through banks (including Japan Post Bank) and pension funds (Figure III.1). This does not include JGBs financed by the basic public pension (about 10 percent of the total JGBs), which will be paid out to households in the future but is categorized as general government's assets in the flow of funds statistics. ${ }^{25}$

- However, going forward, the role of household sector in providing funds to the JGB market is likely to decline. Micro evidence indicates that as predicted by a standard life-cycle model, the aged in Japan are dissaving once retired (Horioka, 2006), ${ }^{26}$ implying that as population aging progresses the household saving rate will continue to decline. Similarly, using macro data, Edison (2005) finds a significant negative effect of the old-age dependency rate on the household saving rate. Consistent with these findings, the household saving rate has been on a trend decline (Figure III.2). Moreover, recent data (Cabinet Office) have shown that contributions to the decline in the household saving rate from rising consumption (possibly owing to population aging) have been growing since FY2003 (Figure III.2). With population aging, the saving rate is expected to decline further from the current level (2.2 percent as of FY2007) and could reduce inflows into the market.

\footnotetext{
${ }^{24}$ There is some empirical evidence consistent with the view that the yields' response to the debt level is nonlinear and becomes significant once the debt exceeds a certain threshold (e.g., Faini, 2006; Ardagna, Caselli, and Lane, 2004), although determining such a threshold in the case of Japan is difficult. In this regard, the pickup in JGB yields (although relatively limited) in early 2009 following announcements of fiscal stimulus measures might suggest an increased risk premium perceived by market participants.

${ }^{25}$ Other indirect holdings of JGBs by the household sector which are not included in the figure are possible. For example, a part of the JGBs holdings by the nonfinancial sector, whose equities the household sector owns, could be included in them.

${ }^{26}$ Horioka, Kasuga, Yamazaki, and Watanabe (1996) found similar results. On the other hand, earlier studies (e.g., Hayashi, 1989; Hayashi, Ando, and Ferris, 1988) found that the aged were saving, but they failed to control for employment status.
} 
Figure III.1: Flow of Funds of the Household Sector (In trillions of yen)

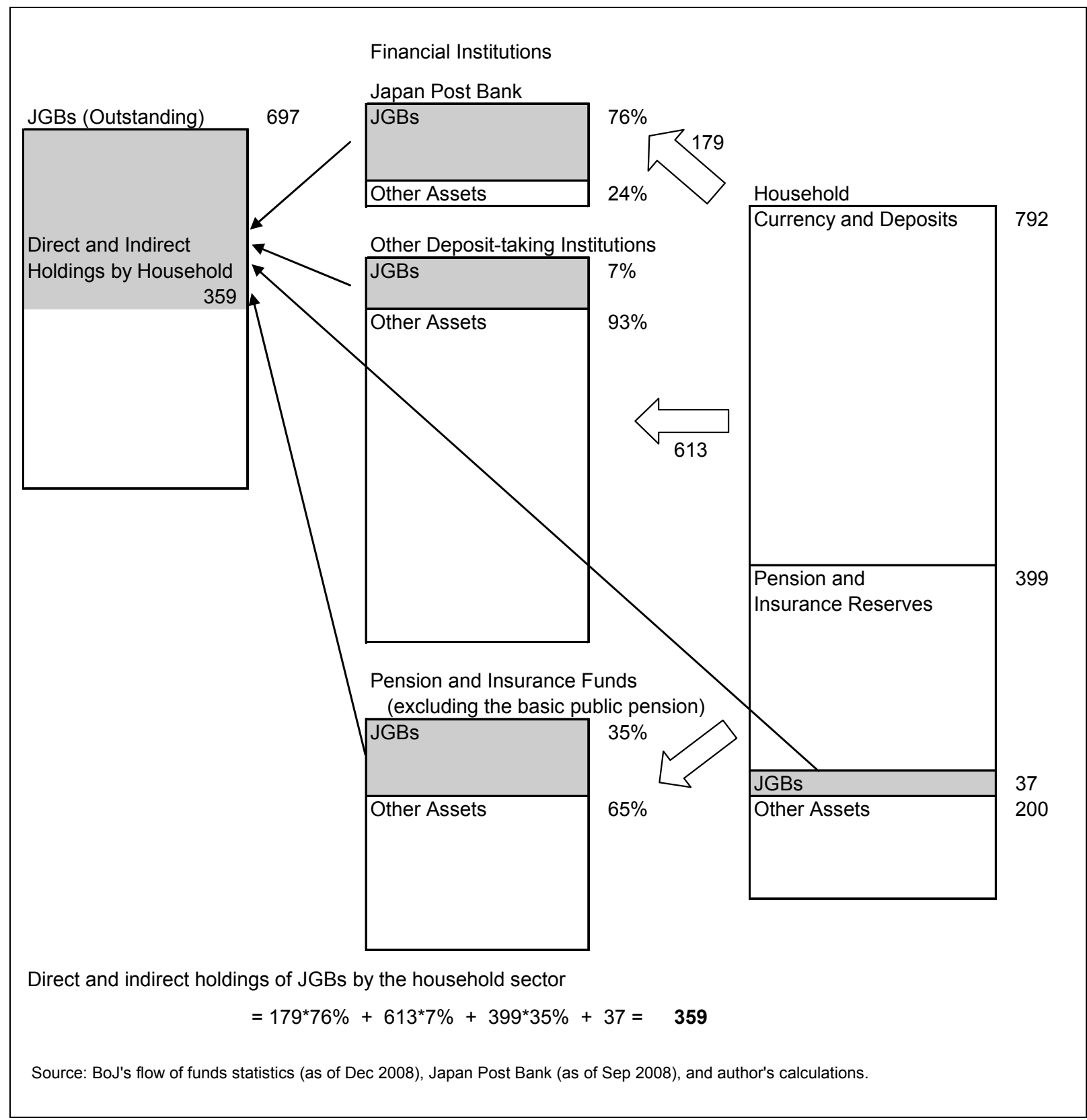


Figure III.2. Japan's Household Saving Rate

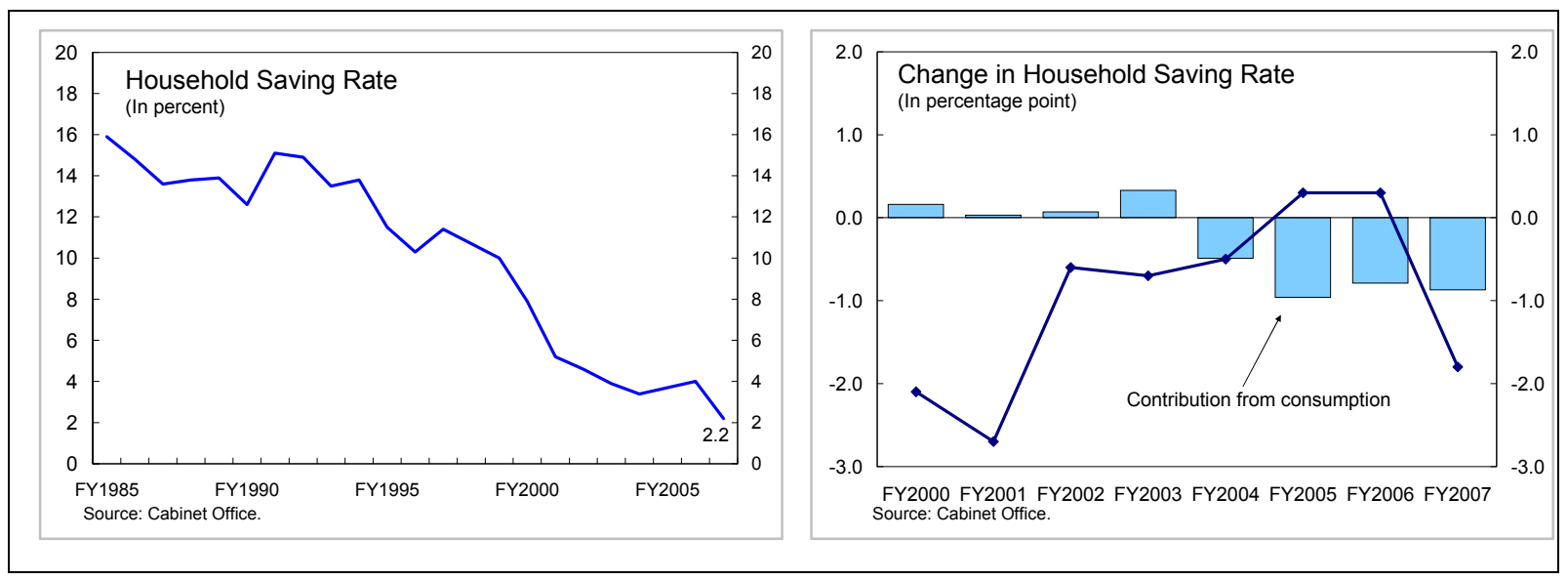

- Without policy adjustment, the space for household assets to absorb public debt will continue to shrink over the medium-term. The author's simulation indicates that based on current trends, gross public debt (including FILP liabilities) in 2015 could exceed gross households' financial assets, assuming the household saving rate remains at 2.2 percent. ${ }^{27}$ Excluding FILP liabilities, the cross-over could emerge around $2020 .{ }^{28}$ Although these results do not imply any specific turning point for public debt financing, they suggest that if current trends continue, domestic financing could become more difficult toward the mid-2010s, placing a premium on other sources of funding, including from overseas.

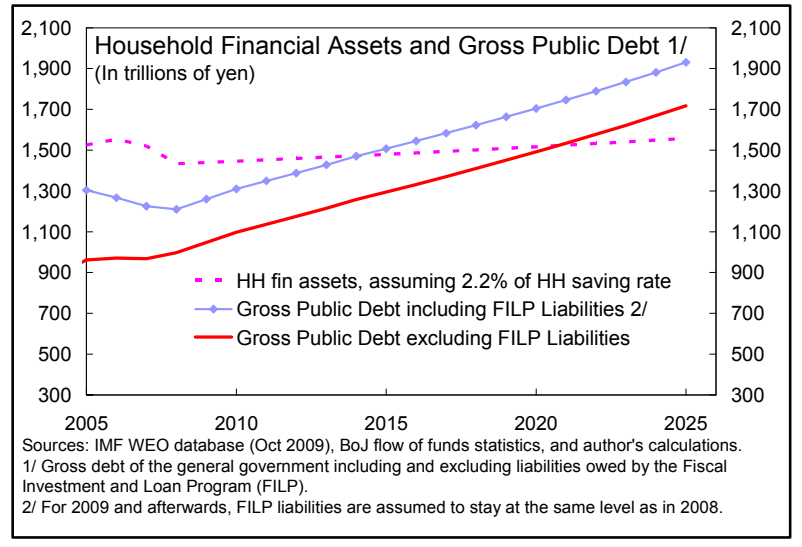

\section{Financial Sector}

- At the same time, financial reforms that have given institutional investors more flexibility could also affect the market capacity to absorb public debt. For example,

${ }^{27} 2.2$ percent is the household saving rate in FY2007. Macro and fiscal forecasts through 2014 are from the IMF WEO database (October 2009). After 2014, the author assumes that real GDP growth and the inflation rate will converge to 1.2 and 1.0 percent, respectively. No consumption tax increase is assumed.

${ }^{28}$ Under the same assumptions, net general government debt (excluding FILP) could exceed net households financial assets about 5 years later. 
changes in the investment behavior by the Government Pension Investment Fund may affect the JGB market beyond a decline in contributions arising naturally from aging; the Government Pension Investment Fund no longer has an obligation to purchase JGBs, which the FILP issues (FILP bonds), and is now looking to expand its investment in risky assets. ${ }^{29}$ Similarly, the Japan Post Bank is now allowed to expand its non-JGB investment. Given the huge size of assets held by these institutions, even a moderate shift from JGBs to other assets could have a significant impact on the market (e.g., 10 percent shift would amount to $¥ 20-30$ trillion (4-6 percent of GDP)).

- A decline in home bias among private financial institutions (Walker, 2005) could also affect the market's absorptive capacity in the medium-term. ${ }^{30}$ In the current global financial turmoil, domestic (institutional) investors may have temporarily sought safety in domestic assets including JGBs. However, appetite for risky foreign assets could return once financial market conditions recover.

- The BoJ, which currently holds about 8 percent of total JGBs, is likely to continue playing an important role in market stability. Its decision in early 2009 to increase its monthly purchase of JGBs has helped to stabilize market conditions, but over the mediumterm unwinding of monetary easing may require the $\mathrm{BoJ}$ to scale back the size of its JGB holdings.

\section{Other Domestic Sectors}

\begin{tabular}{|lc|}
\hline \multicolumn{2}{|c|}{$\begin{array}{c}\text { BoJ's Monthly Outright Purchase of } \\
\text { Long-term JGBs } \\
\text { (In trillions of yen) }\end{array}$} \\
\hline Before Aug. 2001- & 0.4 \\
Aug. 2001- & 0.6 \\
Dec. 2001- & 0.8 \\
Feb. 2002- & 1.0 \\
Oct. 2002- & 1.2 \\
Dec. 2008- & 1.4 \\
Mar. 2009- & 1.8 \\
\hline Source: BoJ. \\
\hline
\end{tabular}

- $\quad$ The role of the corporate sector and the FILP to facilitate financing of public debt may also become more limited going forward. The financial surpluses in the corporate sector have declined in recent years (around 1 percent of GDP in both 2007 and 2008). In the near-term, they could even turn negative with the sharp decline in profits during the global slowdown. It may also become more difficult to constrain FILP bond issuances (FILP lending has already been cut substantially), suggesting that going forward, the supply of government bonds including FILP bonds could be more directly tied to the overall deficit.

\footnotetext{
${ }^{29}$ As a result of the FILP reform in 2001, the public pension fund and the postal savings stopped lending for public projects through the FILP. During the transitional period after the reform (2001-2007), the public pension fund and the postal savings were required to accept government bonds which the FILP issued.

30 As a result of the "financial big bang" in the late 1990s, households' access to foreign risky assets was improved. For example, investment trusts (including those concentrating on foreign assets) were allowed to be sold through bank windows.
} 


\section{Foreign Sector}

- $\quad$ Given the small foreign holdings of JGBs, shifts in foreign investor behavior are unlikely to have a significant impact for the time being. That said, in the near-term, the possibility of a negative impact on the JGB market of sharp increases in sovereign bond issuances across the world (e.g., through crowding-out of JGBs by other sovereign debt) cannot be ruled out.

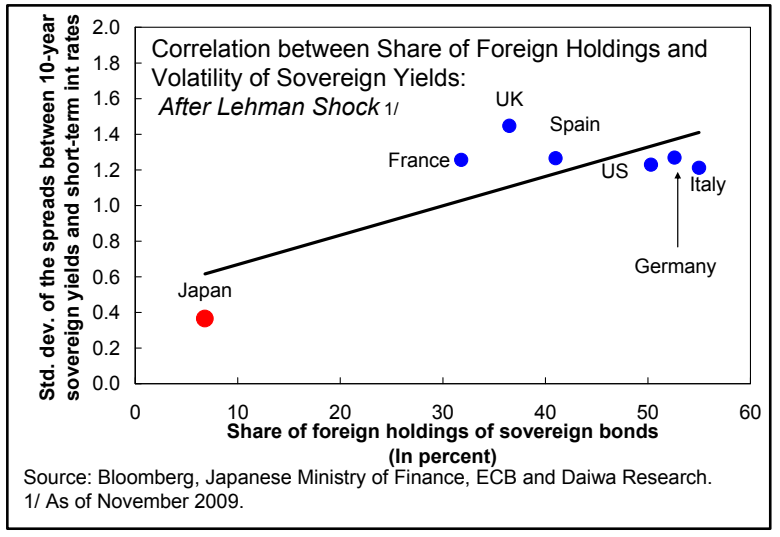

\section{Policy Implications}

19. As discussed in the previous section, JGB yields could be more strongly tied to changes in the deficit and debt looking forward due to the ongoing structural shifts in the JGB market. At the same time, the gross public financing requirement is likely to remain substantial - reaching 50 percent of GDP in 2009 (including rollover of financing bills) and will increase further in line with rising public debt. To ensure the smooth refinancing of the debt, both short-term and medium-term and measures are needed. To ensure stable absorption of debt by the market, the timing of debt issuance and maturity structure should continue to be carefully matched to market conditions. In this respect, the government is making regular contacts with market participants to identify their demand for maturities. Such efforts to communicate with market participants will remain critical. Over the mediumterm, it is critical to establish a credible framework for ensuring fiscal sustainability. The framework will need to feature a clear timetable for comprehensive tax and expenditure reforms to be implemented once the economy recovers.

\section{Conclusions}

20. Historically, Japan's public debt has been financed in a fairly smooth manner. The large pool of household savings and the stable domestic institutional investor base have contributed to keeping yields steady despite the rapid rise in public debt. However, Japan is undergoing rapid population aging, which will likely limit the market's absorptive capacity of public debt. In addition, shifts in institutional investors' behavior could serve to reduce inflows to the market. To maintain market stability, sound public debt management and fiscal consolidation will be critical. 


\section{Appendix}

This appendix details stationarity assumptions on time series data used for the benchmark regressions in the main text.

The results of Dickey-Fuller tests are reported in the table. A unit root test is clearly not rejected across countries for the nominal 10-year government bond yield and the general government net/gross debt (high p-values). The test results for the nominal short-term interest rate are more ambiguous, but all of these four variables are assumed to be nonstationary.

Dickey-Fuller t Statistics

\begin{tabular}{|c|c|c|c|c|c|c|c|}
\hline & Japan & U.S. & U.K. & France & Germany & Canada & Italy \\
\hline \multirow{2}{*}{$\begin{array}{l}\text { Nominal 10-year bond yield } \\
\text { p-value }\end{array}$} & -0.60 & -0.86 & -0.68 & -0.83 & -1.21 & -0.64 & -0.84 \\
\hline & 0.87 & 0.80 & 0.85 & 0.81 & 0.67 & 0.86 & 0.81 \\
\hline \multirow{2}{*}{$\begin{array}{l}\text { Real } 10 \text {-year bond yield } \\
\text { p-value }\end{array}$} & -2.80 & -1.91 & -2.78 & -1.29 & -4.28 & -1.79 & -1.65 \\
\hline & 0.06 & 0.33 & 0.06 & 0.63 & 0.00 & 0.38 & 0.46 \\
\hline \multirow{2}{*}{$\begin{array}{l}\text { Nominal short-term interest rate } \\
p \text {-value }\end{array}$} & -1.55 & -1.49 & -0.94 & -1.39 & -2.58 & -1.51 & -1.32 \\
\hline & 0.51 & 0.54 & 0.78 & 0.59 & 0.10 & 0.53 & 0.62 \\
\hline \multirow{2}{*}{$\begin{array}{l}\text { Real short-term interest rate } \\
\text { p-value }\end{array}$} & -2.14 & -2.01 & -2.28 & -1.52 & -4.60 & -2.11 & -2.07 \\
\hline & 0.23 & 0.28 & 0.18 & 0.52 & 0.00 & 0.24 & 0.26 \\
\hline \multirow{2}{*}{$\begin{array}{l}\text { Inflation } \\
\text { p-value }\end{array}$} & -2.18 & -1.92 & -1.82 & -1.12 & -4.86 & -1.48 & -1.27 \\
\hline & 0.21 & 0.32 & 0.37 & 0.71 & 0.00 & 0.54 & 0.64 \\
\hline \multirow{2}{*}{$\begin{array}{l}\text { Real GDP growth } \\
\text { p-value }\end{array}$} & -3.28 & -4.67 & -4.17 & -4.01 & -4.25 & -4.07 & -5.46 \\
\hline & 0.02 & 0.00 & 0.00 & 0.00 & 0.00 & 0.00 & 0.00 \\
\hline \multirow{2}{*}{$\begin{array}{l}\text { General government primary deficit } \\
\text { p-value }\end{array}$} & -1.47 & -2.24 & -1.50 & -2.52 & -2.82 & -1.71 & -1.20 \\
\hline & 0.55 & 0.19 & 0.53 & 0.11 & 0.06 & 0.43 & 0.67 \\
\hline \multirow{2}{*}{$\begin{array}{l}\text { General government net debt } \\
\text { p-value }\end{array}$} & 1.32 & -1.02 & -1.21 & -1.64 & -0.89 & -0.92 & -3.30 \\
\hline & 1.00 & 0.75 & 0.67 & 0.46 & 0.79 & 0.78 & 0.01 \\
\hline \multirow{2}{*}{$\begin{array}{l}\text { General government gross debt } \\
\text { p-value }\end{array}$} & 2.01 & -0.73 & -1.23 & -1.08 & -0.77 & -0.84 & -1.07 \\
\hline & 1.00 & 0.84 & 0.66 & 0.72 & 0.83 & 0.81 & 0.73 \\
\hline
\end{tabular}

Other variables (real 10-year bond yield, general government primary deficit, real short-term interest rate, inflation, and real GDP growth) are assumed to be stationary, ${ }^{31}$ and assumptions by regression are as follows:

\footnotetext{
${ }^{31}$ This assumption is rather strong, but estimation results of equation (2) using these variables do not give evidence against this assumption. Indeed, for all countries the residual unit root DF tests are rejected at the 5 percent level (Table II.2).
} 


\begin{tabular}{|c|c|c|}
\hline Dependent variable & Main Explanatory Variable & Assumption \\
\hline (1) Nominal 10 -year bond yield & $\begin{array}{l}\text { General government } \\
\text { primary deficit }\end{array}$ & $\begin{array}{l}\text { The 10-year bond yield and the } \\
\text { nominal short-term interest rate are } \\
\text { cointegrated. }\end{array}$ \\
\hline (2) Real 10-year bond yield & $\begin{array}{l}\text { General government } \\
\text { primary deficit }\end{array}$ & $\begin{array}{l}\text { All the variables (real 10-year bond } \\
\text { yield, general government primary } \\
\text { deficit, real short-term interest rate, } \\
\text { inflation, and real GDP growth) are } \\
\text { stationary. }\end{array}$ \\
\hline (3) Nominal 10 -year bond yield & $\begin{array}{l}\text { General government net } \\
\text { debt }\end{array}$ & $\begin{array}{l}\text { The nominal } 10 \text {-year bond yield, } \\
\text { the net debt, and the short-term } \\
\text { interest rate are cointegrated. }\end{array}$ \\
\hline (4) Nominal 10-year bond yield & $\begin{array}{l}\text { General government } \\
\text { gross debt }\end{array}$ & $\begin{array}{l}\text { The nominal } 10 \text {-year bond yield, } \\
\text { the gross debt, and the short-term } \\
\text { interest rate are cointegrated. }\end{array}$ \\
\hline
\end{tabular}




\section{REFERENCES}

Ardagna, Silvia, Francesco Caselli, and Timothy Lane, 2004, "Fiscal Discipline and the Cost of Public Debt Service: Some Estimates from OECD Countries," NBER Working Paper Series, No. 10788.

Baldacci, Emanuele, Sanjeev Gupta and Amine Mati, 2008, "Is it (Still) Mostly Fiscal? Determinants of Sovereign Spreads in Emerging Markets," IMF Working Paper No. 09/259 (Washington: International Monetary Fund).

Bernheim, B. Douglas, 1989, “A Neoclassical Perspective on Budget Deficits," Journal of Economic Perspectives, Vol. 3, No. 2 (Spring), pp. 55-72.

Blanchard, Olivier J., 1985, “Debt, Deficits and Finite Horizons,” Journal of Political Economy, Vol. 93, No. 2, pp. 223-93.

Brook, Anne-Marie, 2003, "Recent and Prospective Trends in Real Long-Term Interest Rates: Fiscal Policy and Other Drivers," OECD Economics Department Working Paper No. 367 (Paris: Organization for Economic Cooperation and Development).

Canzoneri, Matthew B., Robert E. Cumby, and Behzad T. Diba, 2002, "Should the European Central Bank and the Federal Reserve Be Concerned about Fiscal Policy?" in Rethinking Stabilization Policy (Kansas City: Federal Reserve Bank of Kansas City).

Caporale G., and G. Williams, 2002, "Long-term Nominal Interest Rates and Domestic Fundamentals," Review of Financial Economics, Vol. 11.

Carroll, Christopher D., Jody R. Overland, and David N. Weil, 2000, "Saving and Growth with Habit Formation,” American Economic Review, Vol. 90, No. 3 (June), pp. 341355.

Edison, Hali, 2005, "Household Savings in Japan," in Japan-Selected Issues, IMF Country Report No. 05/272 (Washington: International Monetary Fund).

Elmendorf, Douglas W. and N. Gregory Mankiw, 1999, "Government Debt." In John B. Taylor and Michael Woodford (eds.), Handbook of Macroeconomics, Amsterdam: Elsevier Science, Chapter 25.

Engen, Eric and R. Glenn Hubbard, "Federal Government Debts and Interest Rates," NBER Working Paper Series, No. 10681.

Faini, Riccardo, 2006, "Fiscal Policy and Interest Rates in Europe,” Economic Policy, Vol. 21, No. 47, pp. 443-489.

Feldstein, Martin, 1986, "Budget Deficits, Tax rules, and Real Interest Rates," NBER Working Paper Series, No. 1970. 
Gale, William G., and Peter Orszag, 2003, "Economic Effects of Sustained Budget Deficits," National Tax Journal, Vol. 56, No. 3 (September), pp. 463-485.

Hayashi, Fumio, 1989, “Japan's Saving Rate: New Data and Reflections,” NBER Working Paper Series, No. 3205.

Hayashi, Fumio, Albert Ando, and Richard Ferris, 1988, "Life Cycle and Bequest Savings A Study of Japanese and U.S. Households Based on Data from the 1984 NSFIE and the 1983 Survey of Consumer Finances," Journal of the Japanese and International Economies, Vol. 2, No. 4 (December), pp. 450-491.

Hauner, David and Manmohan S. Kumar, 2006, "Fiscal Policy and Interest Rates: How Sustainable Is The "New Economy”?” IMF Working Paper No. 06/112 (Washington: International Monetary Fund).

Horioka, Charles, 1990, "Why is Japan's Household Saving Rate So High? A Literature Survey," Journal of the Japanese and International Economies, Vol. 4, No. 1 (March), pp. 49-92.

Horioka, Charles, 2006, "The Dissaving of the Aged Revisited: The Case of Japan," NBER Working Paper Series, No. 12351.

Horioka, Charles, Norihiro Kasuga, Katsuyo Yamazaki, and Wako Watanabe, 1996, "Do the Aged Dissave in Japan? Evidence from Micro Data," Journal of the Japanese and International Economies, Vol.10, No. 3 (September), pp. 295-311.

International Monetary Fund, 2006, World Economic Outlook: Awash with Cash: Why Are Corporate Savings So High? (Washington, April).

International Monetary Fund, 2009, “Companion Paper-The State of Public Finances: Outlook and Medium-Term Policies After the 2008 Crisis" (Washington).

International Monetary Fund, 2009, Global Financial Stability Report: The Road To Recovery (Washington, October).

Ishikawa, Tsuneo, 1988, "Saving and Labor Supply Behavior of Aged Households in Japan," Journal of the Japanese and International Economies, Vol. 2, No. 4 (December), pp. 417-449.

Iwaisako, Tokuo, 2003, “Household Portfolios in Japan,” NBER Working Paper Series, No. 9647.

Iwaisako, Tokuo, Olivia Mitchell, and John Piggott, 2004, "Strategic Asset Allocation in Japan: An Empirical Evaluation.”

Kinoshita, Noriaki, 2006, "Government Debt and Long-Term Interest," IMF Working Paper No. 06/63 (Washington: International Monetary Fund). 
Laubach, Thomas, 2003, "New Evidence on the Interest Rate Effects of Budget Deficits and Debt," Finance and Economics Discussion Series, Divisions of Research \& Statistics and Monetary Affairs (Washington: Federal Reserve Board).

Nakagawa, Shinobu and Tomoko Shimizu, 2000, "Portfolio Selection of Financial Assets by Japan's Households-Why Are Japan's Households Reluctant to Invest in Risky Assets?" Bank of Japan.

Seater, John J., 1993, "Ricardian Equivalence,” Journal of Economic Literature, Vol. 31, No.1 (March), pp. 142-190.

Walker, Chris, 2005, "Home Bias in Japan," in Japan-Selected Issues, IMF Country Report No. 05/272 (Washington: International Monetary Fund). 